Brit. F. industr. Med., 1966, 23, 222

\title{
Toxicity of Triphenyltin
}

\author{
H. B. STONER \\ From the Toxicology Research Unit, Medical Research Council Laboratories, Carshalton, Surrey
}

The toxicity of triphenyltin has been determined after its acute oral and intraperitoneal administration in rats, guinea-pigs, rabbits, mice, and hens, after feeding it to rats and guinea-pigs, and after its application to the skin of guinea-pigs.

The guinea-pig was the most sensitive species and its growth was inhibited by as little as I p.p.m. triphenyltin acetate in the diet. With higher concentrations in the diet the relationships between the dose and the survival time and between the amount consumed and the acute oral $\mathrm{LD}_{50}$ indicated that triphenyltin accumulated in the guinea-pig.

Compared with those of triethyltin, the effects of triphenyltin appeared relatively non-specific, but there was evidence of an action on the central nervous system although cerebral oedema did not occur. The effects of triphenyltin were quite different from those of diphenyltin which acted mainly as an irritant.

Triphenyltin did not readily penetrate unbroken skin.

The use of triphenyltin as an agricultural fungicide is considered in the discussion.

The fungicidal properties of certain organotin compounds were described by Van der Kerk and Luijten (1954). In vitro, the most active tin compounds were tributyl- and tri-iso-propyl-tin but these were too phytotoxic for agricultural use. Triphenyltin is less active against fungi but is also less phytotoxic and has proved successful as an agricultural fungicide, acting upon a number of the fungi which attack potatoes, beet, and celeriac (Härtel, 1958). The introduction of triphenyltin into agricultural practice has led to a consideration of the hazards which might arise, particularly as the related compound triethyltin is known to be very toxic to both man and animals (Barnes and Stoner, 1959). The results of some experiments on the toxicity of tri- and diphenyl-tin are now reported. They should be considered along with others, notably those of Klimmer (1963, 1964), in assessing the toxicity of triphenyltin.

\section{Methods}

Triphenyltin acetate was obtained from Dr. G. J. M. Van der Kerk (T.N.O., Utrecht) and diphenyltin dichloride was prepared in this laboratory by Dr. D. F. Heath from tetraphenyltin and stannic chloride (Luijten and Van der Kerk, 1955). For injection and skin application these compounds were dissolved in arachis oil. When triphenyltin was added to the diet the acetate

Received for publication November 2, 1965. was dissolved in either arachis oil or ethanol before being mixed with the food. Equivalent volumes of solvent were added to the diet of the controls.

Rats, mice, guinea-pigs, rabbits, and hens were studied. The rats were albinos of the Porton strain and the mice were male $\mathrm{C}_{57} \mathrm{BL} / 6 \mathrm{LAC}$; both were fed M.R.C. diet 4IB (Bruce and Parkes, 1956). The rabbits were cross-bred males fed on diet S.G. I (Short and Gammage, 1959). Male guinea-pigs were obtained from Allington Farm, Porton, Wilts or from other accredited dealers. They were fed on either powdered diet S.G. I with a cabbage supplement or on powdered diet R.G.P. (Dixon \& Sons (Ware) Ltd.) without cabbage. In the latter case the guinea-pigs were housed individually. Adult Rhode Island Red $\times$ Light Sussex hens were used, fed on Laymax Layers V.A. (Cramphorn) with corn and grit. When it was clear that an animal was going to die within the next 24 hours it was killed in order to obtain tissues for analysis or histological examination.

Percutaneous toxicity tests were done on guinea-pigs. An area of the dorsal skin was exposed by clipping about 30 minutes before the application of a $r \cdot 5 \%(w / v)$ solution of triphenyltin acetate in arachis oil. The dose was applied from a syringe fitted with a blunt-tipped needle and spread over the skin surface. The highest dose was given in two portions 30 minutes apart. The animals were kept in wire mesh restraining cages to prevent them licking off the dose (Francis and Barnes, 1963). After 6 hours they were taken out of the cages and the skin was washed with warm water containing Teepol; they were then rinsed and dried.

$\mathrm{LD}_{50} \mathrm{~S}$ and their $95 \%$ confidence limits were calculated by the method of Weil (1952), using groups of 
four animals. The tissues of the animals were not examined histologically in all cases, but, when they were, routine staining methods were used. The water content of the brain and spinal cord was determined by drying in an oven at $105^{\circ} \mathrm{F}$. Statistical comparisons of the means were made according to Student's $t$ test (Fisher, I934).

\section{Results}

\section{Acute Toxicity}

Triphenyltin Data for the acute toxicity of triphenyltin acetate given by different routes to rats, guinea-pigs, and mice are summarized in Table I. As indicated by the $\mathrm{LD}_{50}$ values, triphenyltin was more toxic to all species when given intraperitoneally than when given orally. The degree of difference associated with the two routes was greater for rats and hens than for guinea-pigs, mice, and rabbits. The guinea-pig was the most sensitive species tested, irrespective of the route of administration.

TABLE I

Acute Toxicity of Triphenyltin Acetate

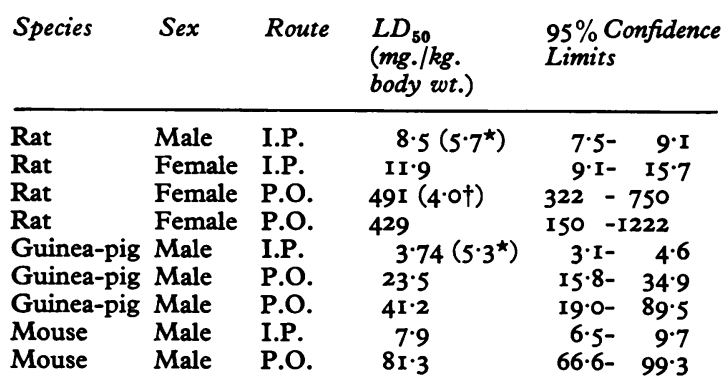

The figures in parenthesis give the corresponding $L D_{50}$ values of triethyltin for comparison from Stoner et al. (1955), Barnes and Stoner (1958), and unpublished results.

$\star$ Triethyltin sulphate. †Triethyltin acetate.

I.P. = intraperitoneal. P.O. = oral.

Rats given pharmacologically effective doses of triphenyltin acetate $(>6 \mathrm{mg}$. $/ \mathrm{kg}$. body weight intraperitoneally) became quiet and ill, and when the dose was large enough there was progressive weakness culminating in death. The rapid onset of weakness, which was a striking feature of triethyltin poisoning (Stoner, Barnes, and Duff, 1955), did not occur, and symptoms appeared more slowly. Excitability was seen in female rats given $6-8 \mathrm{mg}$. triphenyltin acetate $/ \mathrm{kg}$. intraperitoneally.

Mice resembled rats in their response to triphenyltin.

Guinea-pigs showed more definite symptoms with loss of weight, generalized weakness, and paralysis of the hind-limbs.
In all three species the survival time was approximately inversely proportional to the dose but death sometimes occurred up to seven days after intraperitoneal doses and up to 12 days after a single oral dose. Some later deaths occurred after intraperitoneal doses but as they could not be attributed directly to triphenyltin they were excluded from the calculation of the $\mathrm{LD}_{50}$ s. Necropsy showed that these deaths were due to volvulus or other forms of intestinal strangulation by adhesions in the peritoneal cavity. Deaths from this cause have been seen in other experiments where arachis oil has been used as a vehicle for intraperitoneal injections.

The intraperitoneal $\mathrm{LD}_{50}$ of triphenyltin acetate in the rabbit was about $16 \mathrm{mg}$. $/ \mathrm{kg}$. It was less toxic by mouth; $140 \mathrm{mg}$. $/ \mathrm{kg}$. killed two out of three rabbits. The effects differed from those seen in the other three species. Almost immediately after the intraperitoneal injection there was marked vasodilatation in the ears and hyperpnoea. These changes were reversible and with non-fatal doses were usually the only ones seen. With fatal doses generalized muscular weakness developed. The rabbit lay prostrate on its side with slow respirations, and death occurred suddenly after a few hours but terminal convulsions, like those seen in triethyltin poisoning in the rabbit (Stoner et al., 1955), did not occur. The immediate cause of death was not established. Delayed deaths were not seen in rabbits given triphenyltin intraperitoneally.

After oral doses the symptoms appeared more slowly. Little was seen during the first 24 hours after $140 \mathrm{mg} . / \mathrm{kg}$. Then weakness and unsteadiness of gait with head drop developed, becoming progressively worse until the rabbit lay on its side breathing slowly. The muscles of the hind-limbs were not flaccid and there were exaggerated withdrawal and crossed-extensor reflexes. Death occurred after one to three days. In a rabbit which survived an oral dose of $160 \mathrm{mg}$. $/ \mathrm{kg}$. severe symptoms of the above nature were present for three days followed by slow recovery.

Hens showed symptoms after the intraperitoneal injection of $20 \mathrm{mg}$. triphenyltin acetate $/ \mathrm{kg}$., and $40 \mathrm{mg}$. $/ \mathrm{kg}$. killed two of four hens. Symptoms appeared after about 24 hours and comprised unsteadiness of gait and difficulty in landing. These became progressively worse, leading to generalized weakness and death after a further 24 to 48 hours. Hens were insensitive to oral doses, and $300 \mathrm{mg}$. $/ \mathrm{kg}$. by this route gave no symptoms at all.

The percutaneous toxicity tests are summarized in Table II. Triphenyltin did not appear to have any action on the skin itself nor did it penetrate unbroken skin very readily. 
TABLE II

Percutaneous Toxicity of Triphenyltin Acetate in the GuINEA-PIG

\begin{tabular}{lll}
$\begin{array}{l}\text { Dose } \\
\text { (mg./kg.) }\end{array}$ & Mortality $\dagger$ & Survival Time \\
\hline 30 & $0 / 2$ & - \\
60 & $0 / 2$ & - \\
90 & $0 / 2$ & - \\
180 & $3 / 8$ & 22 hrs. ${ }^{\star} ; 22$ hrs.*; I I days
\end{tabular}

The total number of animals in the group is shown in the denominator and the number of dead in the numerator.

*These two guinea-pigs had an abrasion of the skin on the upper part of the hind-limbs as a result of being pushed through the wire mesh at the end of the cages. This was prevented in subsequent experiments.

Diphenyltin All four rats given the smallest intraperitoneal dose of $15.3 \mathrm{mg}$. $/ \mathrm{kg}$. died within 48 hours. Signs of peritoneal irritation were seen shortly after the injection, and at death there was a large peritoneal exudate. With larger doses fluid was also found in the pleural cavity and there was marked engorgement of the peritoneal vessels. After $100 \mathrm{mg}$. $/ \mathrm{kg}$. the rats showed immediate signs of peritoneal irritation; generalized weakness followed and there was difficulty with respiration. They finally became stuporose and died within eight hours. Pulmonary oedema was seen in some cases.

Diphenyltin dichloride was less irritant when given by mouth. Doses up to $160 \mathrm{mg}$. $/ \mathrm{kg}$. caused only transient malaise in the rats, and there was no macroscopical evidence of tissue damage at necropsy four to five days later. After $256 \mathrm{mg}$. $/ \mathrm{kg}$. no deaths occurred within four days, but at necropsy all four rats showed evidence of damage to the fundus of the stomach and in one the stomach was grossly dilated. The colon and caecum were also dilated with abnormally bulky and fluid contents. The caecal contents were examined bacteriologically and Pseudomonas pyocyanea and Proteus were the only organisms recovered. These bacteria are not usually present in the caeca of our rats. On increasing the dose to $410 \mathrm{mg}$. $/ \mathrm{kg}$. or more, deaths occurred in an irregular fashion, sometimes after several days. The cause of death was not very clear. If death occurred early the symptoms were similar to those seen in rats given diphenyltin intraperitoneally. After these larger doses necropsy frequently showed evidence of past damage to the gastro-intestinal tract, and death may have been secondary to this.

\section{Feeding Experiments}

Rat Rats did not find diets containing up to 200 p.p.m. very palatable, and failure to eat them was probably the main reason for the slow gain in weight during the first few weeks of such an experi- ment (Fig. I). However, after this initial period more food was eaten and the growth rate was not very different from that in controls fed ad libitum, although neither the treated rats nor their pair-fed controls attained the body weight of controls eating freely (Fig. I). A similar picture can be reproduced by restricting the diet of normal rats for a week just sufficiently to inhibit growth and then giving food ad libitum.

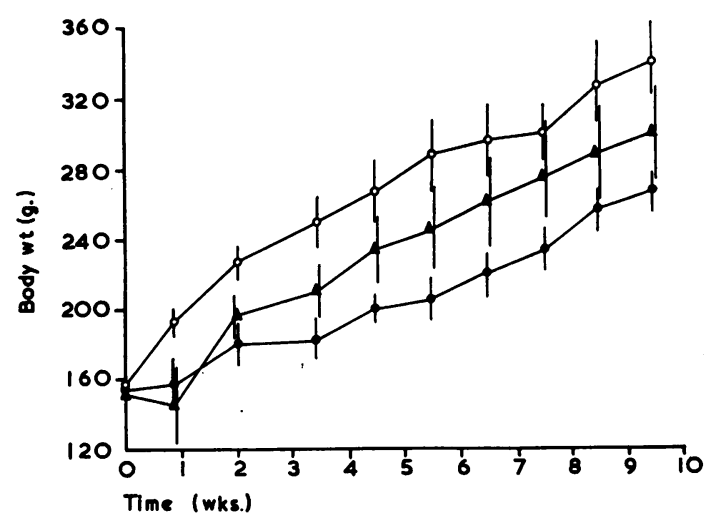

FIG. I. Body weight (mean \pm S.D.) of rats fed diet containing 200 p.p.m. triphenyltin acetate pair-fed controls $\boldsymbol{\Delta} \longrightarrow \boldsymbol{\Delta}$; controls fed ad libitum $\mathrm{O} \longrightarrow$.

In the experiment shown in Fig. $I$, at the end of the tenth week the concentration of triphenyltin acetate was increased to 300 p.p.m. After a further three weeks the rats began to lose weight although the pair-fed controls continued to gain. The treated rats became ill and five of them died after being on the diet containing 300 p.p.m. for II7, II9, I28, 133 , and 168 days respectively. One of these rats died of middle ear disease but the cause was not established in the others. The remaining rat was killed after being on the 300 p.p.m. diet for $28 \mathrm{I}$ days. It then weighed $235 \mathrm{~g}$., $50 \mathrm{~g}$. less than when it had been put on this diet at the end of the tenth week of the experiment. There were no deaths among the controls. Although the treated rats became ill and weak before they died, they did not show any characteristic symptoms.

Guinea-pig In the first experiments (Table III) the guinea-pigs were housed together in groups of four to five and fed powdered diet S.G.I supplemented with about $50 \mathrm{~g}$. of cabbage twice a week. The addition of triphenyltin to this diet seemed to reduce its palatability. Except at the highest level the rate of increase in the body weight of the treated animals was the same as in the pair-fed controls. 
TABLE III

Effect of Adding Triphenyltin Acetate to Powdered S.G. I Diet Fed to Guinea-pigs

\begin{tabular}{|c|c|c|c|c|}
\hline $\begin{array}{l}\text { Exp. } \\
\text { No. }\end{array}$ & $\begin{array}{l}\text { Conc. of Tri- } \\
\text { phenyltin Acetate } \\
(p . p . m .)\end{array}$ & Mortality $\dagger$ & $\begin{array}{l}\text { Survival } \\
\text { Period } \\
\text { (days) }\end{array}$ & $\begin{array}{l}\text { Duration } \\
\text { of Expt. } \\
\text { (days) }\end{array}$ \\
\hline \multirow[t]{5}{*}{$S_{33}$} & $\circ$ & $0 / 4$ & - & \multirow[t]{5}{*}{95} \\
\hline & o* & $0 / 5$ & - & \\
\hline & 10 & $2 / 5$ & $49 ; 73$ & \\
\hline & 20 & $\mathrm{I} / 5$ & 49 & \\
\hline & 60 & $4 / 5$ & $\begin{array}{l}25 ; 30 ; 30 ; \\
35\end{array}$ & \\
\hline \multirow[t]{4}{*}{$S_{36}$} & 0 & $2 / 5$ & $161 ; 188$ & \multirow[t]{4}{*}{392} \\
\hline & $0^{\star}$ & $1 / 5$ & 209 & \\
\hline & $\mathbf{I}$ & $1 / 5$ & $67^{\star}$ & \\
\hline & 5 & $3 / 5$ & 8; IO; II & \\
\hline \multirow[t]{4}{*}{$S_{38}$} & 0 & $1 / 5$ & 62 & \multirow[t]{4}{*}{385} \\
\hline & $0^{\star}$ & $2 / 5$ & $70 ; 74$ & \\
\hline & $\begin{array}{l}5 \text { reduced to } 2 \cdot 5 \\
\text { after } 17 \text { days }\end{array}$ & $4 / 5$ & $\begin{array}{l}67 ; 67 ; 138 ; \\
356\end{array}$ & \\
\hline & $\begin{array}{l}20 \text { reduced to } 10 \\
\text { after } 17 \text { days }\end{array}$ & $5 / 5$ & $\begin{array}{c}61 ; 63 ; 68 ; \\
74 ; 88\end{array}$ & \\
\hline
\end{tabular}

†The total number of animals in the group is shown in the denominator and the number of dead in the numerator.

In each experiment the pair-fed controls, shown as $0^{\star}$, were paired to the group on the highest dose of triphenyltin as far as possible.

$\star$ Died of middle ear disease.
Accurate pair-feeding was difficult because they tended to scatter the powdered food. Compared with guinea-pigs given food ad libitum, the growth rate of the treated guinea-pigs was reduced when the concentration of triphenyltin acetate exceeded 5 p.p.m. The effects of higher doses are shown in Figure 2.

An unsatisfactory feature of these experiments was the occurrence of deaths among the controls. Some of these deaths may reflect the difficulty of keeping guinea-pigs on an incomplete, powdered diet coupled with a decreased food intake in the pair-fed controls. The only treated group in which the mortality rate was not increased by triphenyltin acetate was that in experiment $S_{3} 6$ receiving I p.p.m., although one of this group had to be killed after 67 days because of middle-ear disease.

Because of these difficulties the tests were repeated and extended using a complete diet (RGP), which did not require added greenstuff, and housing the guinea-pigs individually so that food consumption could be measured more accurately. The results are shown in Table IV.

The effects of triphenyltin were best seen in the animals which died. By the end of the first week

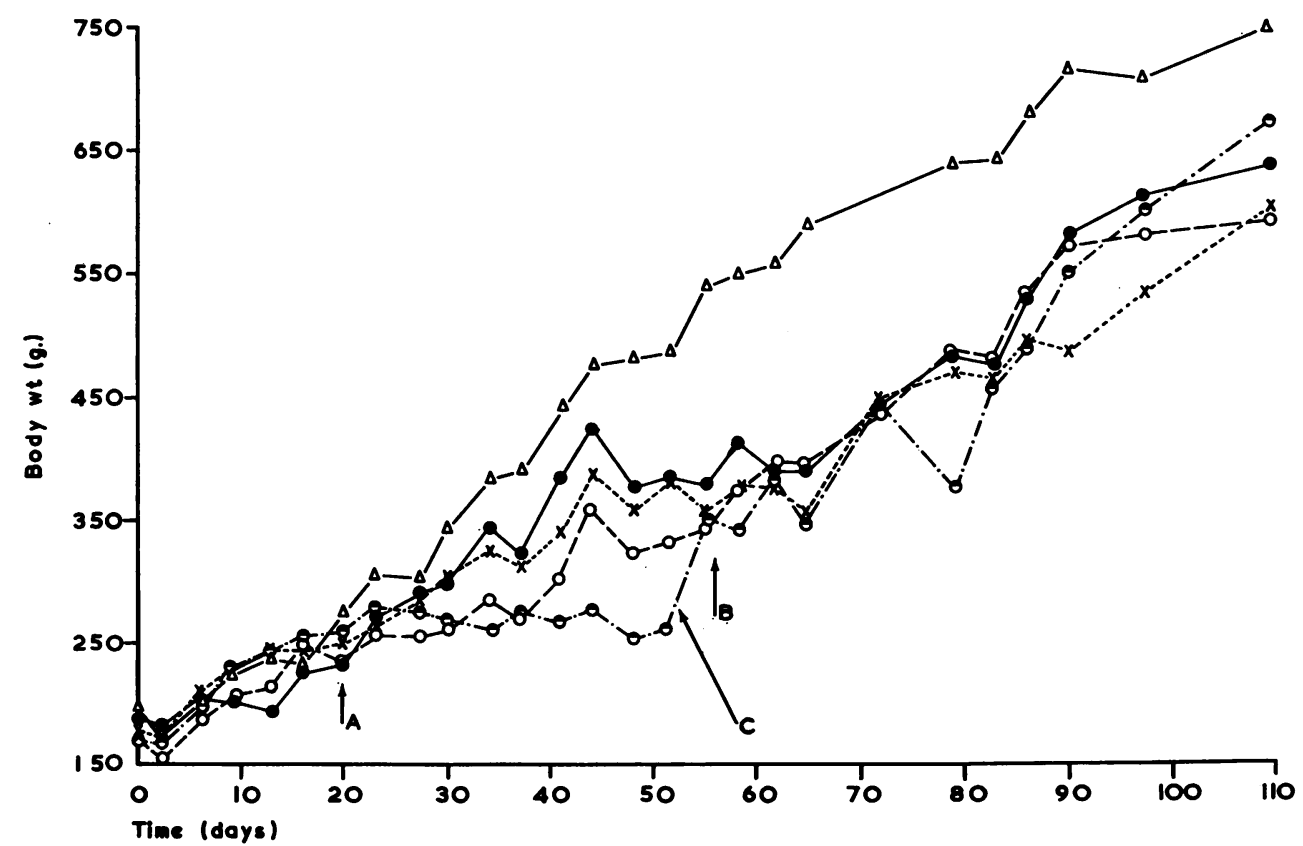

FIG. 2. Mean body weight of guinea-pigs fed diets containing triphenyltin acetate (Expt. S33, Table III).

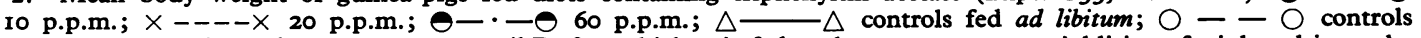
pair-fed to the guinea-pigs on 60 p.p.m. until B after which pair-fed to those on ro p.p.m. Addition of triphenyltin to the diet commenced at $A$. $C=$ point when four of the five guinea-pigs fed 60 p.p.m. had died. 
TABLE IV

\begin{tabular}{|c|c|c|c|c|c|}
\hline \multirow[b]{2}{*}{$\begin{array}{l}\text { Exp. } \\
\text { No. }\end{array}$} & \multicolumn{5}{|c|}{ Effect of Adding Triphenyltin Acetate to Powdered RGP Diet Fed to Guinea-pigs } \\
\hline & $\begin{array}{l}\text { Conc. of } \quad: \\
\text { Triphenyltin } \\
\text { Acetate (p.p.m.) }\end{array}$ & Mortality & $\begin{array}{l}\text { Survival Period } \\
\text { (days) }\end{array}$ & $\begin{array}{l}\text { Duration of } \\
\text { Expt. } \\
\text { (days) }\end{array}$ & $\begin{array}{l}\text { Total Amount of Tri- } \\
\text { phenyltin Acetate } \\
\text { (mg./kg.) Consumed at } \\
\text { Death (mean } \pm \text { S.D.) }\end{array}$ \\
\hline \multirow[t]{2}{*}{ S39 } & o & $\mathbf{I} / 9$ & 87 & 283 & - \\
\hline & 5 & $2 / 9$ & $26 ; 95$ & & - \\
\hline \multirow{2}{*}{$\mathbf{S}_{40}$} & 0 & $0 / 9$ & - & $3 \mathbf{I}$ & - \\
\hline & 50 & $9 / 9$ & $17 ; 21 ; 22 ; 23 ; 23 ; 23 ; 24 ; 29 ; 3 I$ & & $54 \pm 14$ \\
\hline \multirow[t]{2}{*}{$\mathbf{S}_{43}$} & 0 & $0 / \mathbf{I} \mathbf{I}$ & - & 200 & - \\
\hline & $\begin{array}{l}25 \\
50\end{array}$ & $\begin{array}{l}5 / 6 \\
6 / 6\end{array}$ & $\begin{array}{l}30 ; 36 ; 39 ; 68 ; 77 ; \\
15 ; 22 ; 22 ; 25 ; 26 ; 29\end{array}$ & & $\begin{array}{l}94 \pm 35 \\
70 \pm 23\end{array}$ \\
\hline \multirow[t]{2}{*}{$S_{44}$} & 0 & $0 / 5$ & - & 105 & - \\
\hline & 6 & $1 / 5$ & 69 & & - \\
\hline \multirow{2}{*}{$S_{45}$} & o* & $2 / 7$ & $32 ; 72$ & 96 & - \\
\hline & I & $0 / 7$ & - & & - \\
\hline
\end{tabular}

$\dagger$ The total number of animals in the group is shown in the denominator and the number of dead in the numerator.

The controls were pair-fed to the group on the highest dose of triphenyltin except for the group marked with an asterisk which were fed ad libitum.

on 50 p.p.m. they had all begun to lose weight, and this continued until death. (The pair-fed controls maintained their body weight.) After about I4 days all the treated guinea-pigs showed some weakness, especially of the hind-legs, and had a rather odd, 'humped' gait. Weakness progressed, and when they were moribund they lay on their sides. Death often occurred quite suddenly and was difficult to predict within 24 hours. A similar pattern of change was seen in all the treated guinea-pigs which died. Survivors in affected groups showed episodes of loss of weight, slight weakness, and loss of fur from which they recovered. Unexplained deaths still occurred among the controls but rather less frequently than before. Scattering of the food still occurred but it was possible to keep a better account of food consumption. This was reduced by the addition of triphenyltin to the diet (Fig. 3). The most striking feature of the results in Table IV is that the total amount of triphenyltin acetate consumed by the guinea-pigs on 50 p.p.m. before death was within the $95 \%$ confidence limits of one estimate of the acute oral $\mathrm{LD}_{50}$ dose for that species, and that the amount consumed by those on 25 p.p.m. before death was not much greater. The survival time of those which died on 25 p.p.m. was about twice that of the animals fed 50 p.p.m.

At necropsies on guinea-pigs which died or which had been killed when moribund the stomach was usually empty and the bulk of the intestinal contents was reduced. The body was very wasted but no other characteristic changes were seen. In some, but not all, there were lung changes such as patchy consolidation suggesting terminal pulmonary infection. In some also there was an increase in lipid in the parenchymal cells of the liver, probably reflect- ing the very low food intake during the few days before death. In experiment $\mathrm{S}_{3} 8$ (Table III) the faeces of the animals on the higher dose rate were examined bacteriologically after 49 days on the diet. The types of organism cultured from the faeces of these animals were the same as from the faeces of their controls. At the end of experiment $\mathrm{S}_{44}$ (Table IV) the testes were examined. Their weight, as a percentage of body weight, and histological appearance were the same in the treated and control animals.

The lowest dosage rate tested was I p.p.m. (Table IV). Although the guinea-pigs receiving this dose appeared well during the 95 days of the test, their growth rate was adversely affected (Fig. 4). The controls in this experiment were fed ad libitum but food consumption in the two groups was the

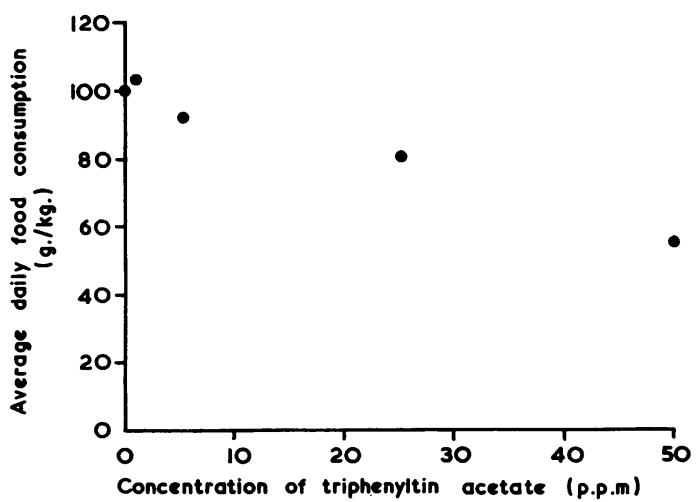

FIG. 3. Approximate daily food consumption by guinea-pigs fed diet RGP with added triphenyltin acetate. Data from experiments in Table IV. 


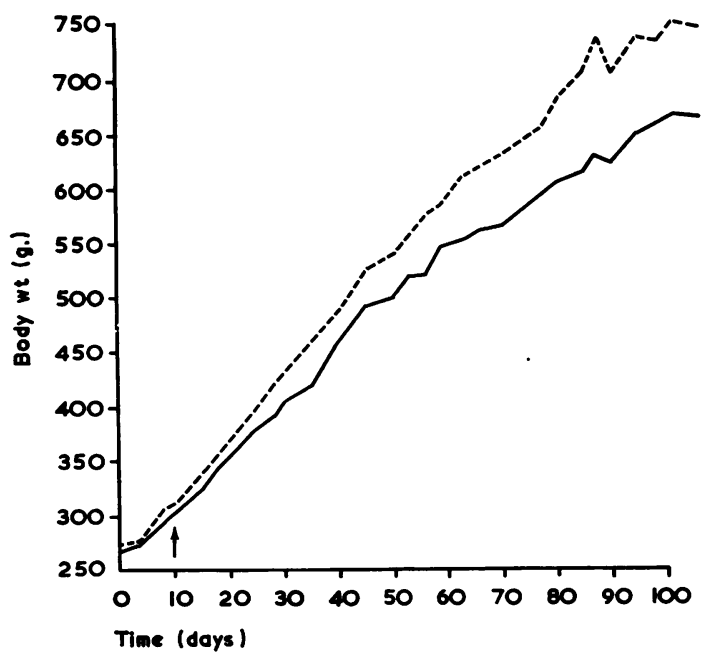

FIG. 4. Average body weight in seven guinea-pigs fed RGP diet ad libitum (---) and in seven guinea-pigs fed RGP diet + I p.p.m. triphenyltin acetate (-). Triphenyltin feeding commenced at the arrow. Data from experiment $S_{45}$.

same. Two deaths occurred among the controls for which no obvious cause was found. The slopes of the growth rate curves for the individual guineapigs were calculated and the means compared ( $t$ test). The mean for the treated guinea-pigs was significantly $(P<0.01)$ less than that for the controls. From the amount of food eaten by these guinea-pigs their daily intake of triphenyltin acetate would have been about $0.1 \mathrm{mg} . / \mathrm{kg}$.

Water Content of the Central Nervous System An increase in the water content of the white matter of the brain and spinal cord is a characteristic feature of triethyltin poisoning (Magee, Stoner, and Barnes, 1957), and a similar lesion was sought in triphenyltin poisoning.

The guinea-pigs studied from this point of view were from the experiments recorded in Tables III and IV, from a further experiment in which Io guinea-pigs were fed 50 p.p.m. triphenyltin acetate for 21 days, and from an experiment in which seven guinea-pigs were examined 48 hours after an oral dose of $57.8 \mathrm{mg} . / \mathrm{kg}$. when they were severely affected. In none was the water content of the brain or spinal cord significantly different from that in the controls.

The brain and spinal cord were also examined in six rats after 72 days on a diet containing 200 p.p.m. triphenyltin acetate and in four rats three days after a single oral dose of $500 \mathrm{mg} . / \mathrm{kg}$. The water content of these tissues was unaltered.
Histological examination of the brain and spinal cord from these guinea-pigs and rats did not show the separation of the fibres in the white matter seen in triethyltin poisoning (Magee et al., 1957).

\section{Discussion}

These experiments show that triphenyltin is a highly toxic compound, particularly in the guineapig. The greater sensitivity of the guinea-pig, compared with that of other laboratory species, was also observed by Klimmer (1963), and the present results confirm our earlier remarks on its susceptibility to triphenyltin (Stoner et al., I955). The toxicity $\left(L_{50}\right)$ of triphenyltin in these tests on guinea-pigs (oral and intraperitoneal), rats (intraperitoneal), and rabbits (intraperitoneal) was of the same order as that reported by Klimmer (1963, 1964). However, he gave a much lower value for the oral $\mathrm{LD}_{50}$ in the rat- $136 \mathrm{mg} . / \mathrm{kg}$. This value was obtained with triphenyltin acetate suspended in tylose and may reflect the difference in the vehicle (Heath, 1963). Klimmer also gave a figure of $450 \mathrm{mg}$. $/ \mathrm{kg}$. for the percutaneous $\mathrm{LD}_{50}$ of triphenyltin acetate in the rat. This, together with the results of our percutaneous toxicity tests on guinea-pigs, suggests that triphenyltin does not easily penetrate unbroken skin.

The results of the acute intraperitoneal tests showed that the intrinsic toxicity of triphenyltin was high in all the species studied. Indeed, in terms of $\mathrm{LD}_{50} \mathrm{~s}$, its intrinsic toxicity was not very different from that of triethyltin, the most toxic trialkyltin compound (Barnes and Stoner, 1958). From one point of view this is perhaps not surprising for the intrinsic toxicity of several lower members of the trialkyltin series is of the same order (Stoner et al., 1955; Barnes and Stoner, 1958), and in vitro (W. N. Aldridge, personal communication) triphenyltin inhibits oxidative phosphorylation by isolated liver mitochondria and the activity of brain microsomal adenosine triphosphatase to about the same degree as tri- $n$-butyltin (Aldridge and Street, 1964). Nevertheless, triphenyltin differed in its toxicological properties from triethyltin in several respects.

While our previous work (Barnes and Stoner, 1958) had suggested that the toxicity of triethyltin is not much altered by the route of administration, this was not the case with triphenyltin. Species differ markedly in their ability to absorb triphenyltin from the intestinal tract. Poor absorption has been reported in ruminants (Brüggemann, Barth, and Niesar, 1964; Herok and Götte, 1963). Guineapigs absorbed it readily but rats only poorly. This might be related, in part, to the way in which it was presented to the intestinal mucosa but could not be 
explained by breakdown of the triphenyltin in the gut of the rat (Heath, 1963). The situation in guinea-pigs is interesting because they are much more resistant to dietary triethyltin than rats (unpublished results).

Like triethyltin (Cremer, 1957), triphenyltin is not readily metabolized in the body (Heath, 1963) and, on the evidence so far available, its toxicological effects should be attributed to the action of the unchanged radical. Diphenyltin, which might be postulated as the first breakdown product, behaved quite differently, its irritant properties resembling those of some other dialkyltin compounds (Barnes and Stoner, 1959).

Not only is triphenyltin not readily metabolized but its elimination from the body is slow. Its persistence in guinea-pigs is indicated by the similarity between the amounts consumed by those dying on diets containing 25 and 50 p.p.m. and the acute oral $\mathrm{LD}_{50}$ and by the logarithmic mean survival time on 25 p.p.m. (excluding the guinea-pig which survived) being twice that on 50 p.p.m. (experiment $\mathrm{S}_{43}$, Table IV). Striking evidence of accumulation has also been presented by Scholz (1965) although his guinea-pigs were not as sensitive as ours, surviving 50 p.p.m. for as long as 77 days. The reason for this difference in sensitivity is not clear but could be due to differences in the basic diet. These results are in good agreement with those obtained by Heath (1963, I965) using ${ }^{113} \mathrm{Sn}$-triphenyltin. In a limited series of experiments he found no fall during the first 10 days in the concentration of triphenyltin which had entered the brain after a single oral dose. In rats, triphenyltin disappeared more rapidly, having a halflife of about three days in the brain. From the biological and analytical data there seems to be good evidence for the accumulation of triphenyltin in the body because of the slow excretion and metabolism of what is absorbed, and this accounts for the adverse effects of repeated small doses.

The mode of action of triphenyltin cannot be described accurately. Tauberger (1963), from experiments on anaesthetized cats, claimed that it had an action on the central nervous system like triethyltin. As pointed out above, its effects on isolated biochemical systems closely resemble those of the lower trialkyltin compounds, especially of tri$n$-butyltin. Nevertheless, for the most part, the clinical syndrome of triphenyltin poisoning lacks the specific features of central nervous system involvement seen with the lower trialkyltins and is difficult to distinguish from that of a generalized depressive illness. The best clinical evidence of an effect on the nervous system was found in the hen. Triphenyltin penetrates the brain of the rat and guinea-pig and persists there for quite a long time (Heath, 1963;
1965) but when slices prepared from the brains of rats, severely ill four hours after the intraperitoneal injection of $30 \mathrm{mg}$. triphenyltin acetate $/ \mathrm{kg}$., were examined their metabolic behaviour was the same as that of brain slices from normal rats (J. E. Cremer, personal communication). In this respect triphenyltin differed from triethyltin (Cremer, 1957). It also differed in not causing oedema of the central nervous system. According to G. J. Van Esch and his colleagues (personal communication), triphenyltin can cause cerebral oedema in both rats and guinea-pigs but we have never found this although we have made repeated attempts. The best evidence for the absence of cerebral oedema came from the rat experiments since it is comparatively difficult to produce cerebral oedema with triethyltin in guinea-pigs (Kalsbeck and Cumings, 1963). Although the intraperitoneal toxicity of triethyltin in the guinea-pig was about the same as in the rat, we were unable to produce cerebral oedema in the guinea-pig in acute experiments. Gross oedema was, however, found at the end of an experiment in which they were fed Io p.p.m. triethyltin acetate for 16 days, followed by 20 p.p.m. for 24 days, 40 p.p.m. for 21 days, and finally 80 p.p.m. for 43 days.

Other biological actions have been described for triphenyltin such as effects on erythro- and leucopoiesis (G. J. Van Esch, personal communication) and a chemisterilant action on insects (Kenaga, 1965) but these types of effect were not sought in our experiments. Klimmer (1964) has suggested that triphenyltin lowers resistance to infection on the basis of an experiment in which $70 \%$ of the rats fed 50 p.p.m. died of intercurrent infection. Our rats were much more resistant to triphenyltin, and secondary infection was not often seen in the treated guinea-pigs which died. Coexistent malnutrition is another possibility. This could have played a part in the death of the guinea-pigs on high dose rates for their food intake was depressed. However, the guinea-pigs on I p.p.m. ate well and appeared normal apart from the slower growth rate.

There are obviously many difficulties to be resolved before one could specify a 'no-effect level' for triphenyltin acetate which could be usefully extrapolated to man. From the present data it appears to be very low, $<0.1 \mathrm{mg} . / \mathrm{kg}$./day. With the usual safety factor of 100 , this would imply an acceptable daily intake for man of less than $0.001 \mathrm{mg}$. $/ \mathrm{kg}$. and would mean that very little triphenyltin could be permitted as a residue in food, certainly less than the I p.p.m. suggested by Hardon, Besemer, and Brunink (1962). Indeed, relevant residues in food could not be estimated by available methods. Fortunately this exercise may be unneces- 
sary as triphenyltin is not a systemic fungicide in celeriac and sugar-beet (Herok and Götte, 1963) or potatoes (A. J. Pieters, personal communication). Provided that it can be shown that triphenyltin does not contaminate the part of the crop which is eaten, its use as an agricultural fungicide would not seem to present a consumer hazard.

My thanks are due to Mrs. J. I. Jenkins for performing the percutaneous toxicity tests, to Mr. A. A. Tuffery for carrying out the bacteriological investigations, and to Mrs. A. Quinnell for her careful and conscientious technical assistance.

\section{REFERENCES}

Aldridge, W. N., and Street, B. W. (1964). Biochem. F., 91, 287.

Barnes, J. M., and Stoner, H. B. (1958). Brit. F. industr. Med., $15,15$.

- - (1959). Pharmacol. Rev., I1, 2 II.

Bruce, H. M., and Parkes, A. S. (1956). f. Anim. Techns. Ass., 7, 54.

Brüggemann, J., Barth, K., and Niesar, K.-H. (I964). Zbl. Vet. Med., Reihe A, II, 4.

Cremer, J. E. (1957). Biochem. F., 67, 87.

Fisher, R. A. (1934). Statistical Methods for Research Workers, 5th ed., pp. 121, 158. Oliver and Boyd, Edinburgh.
Francis, J. I., and Barnes, J. M. (1963). Bull. Wld Hlth Org., 29, 205.

Hardon, H. J., Besemer, A. F. H., and Brunink, H. (1962). Dtsch. Lebensmitt-Rdsch., 58, 349.

Härtel, K. (1958). Tin and its Uses, No. 43, p. 9.

Heath, D. F. (1963). Radiation and Radioisotopes applied to Insects of Agricultural Importance, p. 185. International Atomic Energy Agency.

- (1965). I.A.E.A. Panel on the Use of Radioisotopes in the Detection of Pesticide Residues, Vienna. To be published.

Herok, J., and Götte, H. (1963). Int. F. appl. Radiat., 14, $46 \mathrm{r}$.

Kalsbeck, J. E., and Cumings, J. N. (1963). f. Neuropath. exp. Neurol., 22, 237.

Kenaga, E. E. (1965). F. econ. Entomol., 58, 4.

Klimmer, O. R. (I963). Arzneimittel-Forsch., 13, 432. (1964). Zbl. Vet.-Med., Reihe A, 11, 29.

Luijten, J. G. A., and Van der Kerk, G. J. M. (1955). Investigations in the Field of Organotin Chemistry, p. 112. Tin Research Institute, Greenford.

Magee, P. N., Stoner, H. B., and Barnes, J. M. (1957). f. Path. Bact., 73, 107.

Scholz, J. (1965). Nature, 207, 870.

Short, D. J., and Gammage, L. (1959). F. Anim. Techns. Ass., 9, 62.

Stoner, H. B., Barnes, J. M., and Duff, J. I. (1955). Brit. F. Pharmacol., 10, 16.

Tauberger, G. (1963). Med. exp. (Basel), 9, 393.

Van der Kerk, G. J. M., and Luijten, J. G. A. (I954). $\mathcal{F}$. appl. Chem., 4, 314.

Weil, C. S. (1952). Biometrics, 8, 249. 